\title{
PENGARUH ANALISIS JABATAN, ANALISIS BEBAN KERJA DAN KOMPETENSI TERHADAP KINERJA APARATUR SIPIL NEGARA (ASN) PADA SEKRETARIAT DAERAH KABUPATEN BALANGAN PROVINSI KALIMANTAN SELATAN
}

\author{
Didik Haryanto \\ Sekolah Tinggi Ilmu Ekonomi Pancasetia Banjarmasin \\ Jl. Ahmad Yani Km. 5.5 Banjarmasin \\ didikbalangan@gmail.com
}

\begin{abstract}
This study aims to determine both partially and simultaneously how big the influence of Position Analysis, Workload Analysis and Competence on the Performance of Aparatur Sipil Negara (ASN) at Sekretariat Daerah Kabupaten Balangan Provinsi Kalimantan Selatan and the variables that have a dominant influence on the performance of South Kalimantan Province.

The method used in this study is a quantitative method and with a population of 105 (one hundred and five) people, the sample is taken with a slovin sampling technique of 84 (eighty four) people, the research instrument is validity and reliability testing, classical assumption test (normality test, Multicollinearity, Heteroscedasticity) the data were tested using multiple linear regression.

The results of this study indicate that simultaneously Position Analysis, Workload Analysis and Competence have a significant effect on the Performance of Regional Secretariat Employees of Balangan Regency, South Kalimantan Province, partially Position Analysis, Workload Analysis and Competence have a significant effect on the Performance of Regional Secretariat Employees of Balangan Regency, South Kalimantan Province. and the variable that has a dominant influence on the performance of the Regional Secretariat of Balangan Regency, South Kalimantan Province is Competence. R Square is 0.383, which means that the contribution of all independent variables to the dependent variable is $38.3 \%$, while the remaining $61.7 \%$ is influenced by other factors.
\end{abstract}

Keywords: Job Analysis, Workload Analysis and Competence and Performance.

Abstrak:Penelitian ini bertujuan untuk mengetahui baik secara parsial dan simultan seberapa besar Pengaruh Analisis Jabatan, Analisis Beban Kerja Dan Kompetensi Terhadap Kinerja Aparatur Sipil Negara (Asn) Pada Sekretariat Daerah Kabupaten Balangan Provinsi Kalimantan Selatan serta variabel yang berpengaruh dominan terhadap Kinerja Provinsi Kalimantan Selatan.

Metode yang digunakan dalam penelitian ini adalah metode kuantitatif dan dengan populasi sebanyak 105 (Seratus Lima) orang, diambil sampel dengan teknik sampling slovin sebanyak 84 (Delapan puluh empat) orang, instrument penelitian uji validitas dan uji reliabilitas, Uji Asumsi Klasik (Uji Normalitas, Multikolinieritas, Heteroskedastisidas) data - data diuji dengan menggunakan regresi linear berganda.

Hasil penelitian ini menunjukkan bahwa secara simultan Analisis Jabatan, Analisis Beban Kerja dan Kompetensi berpengaruh signifikan terhadap Kinerja Pegawai Sekretariat Daerah Kabupaten Balangan Provinsi Kalimantan Selatan, secara parsial Analisis Jabatan, Analisis Beban Kerja dan Kompetensi berpengaruh signifikan terhadap Kinerja Pegawai Sekretariat Daerah Kabupaten Balangan Provinsi Kalimantan Selatan dan variabel yang berpengaruh dominan terhadap Kinerja Pegawai Sekretariat Daerah Kabupaten Balangan Provinsi Kalimantan Selatan adalah Kompetensi. R Square sebesar 0,383 yang berarti besarnya variasi sumbangan seluruh variabel bebas terhadap variabel terikatnya adalah $38.3 \%$ sedangkan sisanya $61.7 \%$ dipengaruhi faktor lain..

Kata kunci : Analisis Jabatan, Analisis Beban Kerja dan Kompetensi dan Kinerja.. 


\section{Latar Belakang Masalah}

Analisis Jabatan dapat diartikan sebagai proses pengumpulan informasi tentang jabatan tertentu dan penentuan unsur pokok yang diperlukan untuk menjalankan pekerjaannya. Di sisi lain, Analisis Jabatan juga diartikan sebagai proses yang dilakukan secara sistematis dalam menentukan keterampilan, tugas, dan pengetahuan yang perlu dikuasai SDM untuk melakukan pekerjaan tertentu dalam organisasi. Dari pengertian tersebut, dapat diketahui bahwa Analisis Jabatan ini sangat penting untuk diadakan agar dapat ditentukan kemampuan apa yang harus dimiliki SDM yang akan mengisi jabatan tertentu dalam perusahaan Anda sehingga diisi oleh

Analisis jabatan merupakan pengumpulan informasi mengenai suatu pekerjaan pegawai. Analisis jabatan Pegawai Negeri Sipil diatur dalam Permendagri No. 35 Tahun 2012. Analisis jabatan diperlukan dalam rangka program penataan kelembagaan, ketatalaksanaan dan kepegawaian serta pendidikan yang berbasis pada kinerja. Aspek yang dianalisis adalah pelaksanaan pekerjaan yang menjabarkan fungsi-fungsi yang ada di setiap unit kerja. Instansi pemerintah maupun Satuan Kerja Perangkat Daerah (SKPD) wajib melakukan analisis jabatan. Analisis jabatan dilakukan dalam rangka reformasi birokrasi dimana penerapan prinsip the right man, in the right place and in the right time.

Analisis Beban Kerja adalah teknik manajemen yang dilakukan secara sistematis untuk memperoleh informasi mengenai tingkat efektivitas dan efisiensi kerja organisasi berdasarkan volume kerja. Pelaksanaan analisis beban kerja pada hakekatnya diharapkan agar dapat terpenuhinya tuntutan kebutuhan untuk menciptakan efektivitas dan efisiensi serta profesionalisme sumber daya manusia aparatur yang memadai pada setiap instansi serta mampu melaksanakan tugastugas umum pemerintahan dan pembangunan secara lancar dengan dilandasi semangat pengabdian kepada masyarakat, bangsa dan negara.

Selain itu, pelaksanaan analisis beban kerja dapat menghasilkan suatu tolok ukur bagi pegawai/unit organisasi dalam pembagian tugas serta melaksanakan kegiatannya, yaitu berupa norma waktu penyelesaian pekerjaan, tingkat efisiensi kerja, dan standar beban kerja dan prestasi kerja, menyusun formasi pegawai, serta penyempurnaan sistem prosedur kerja dan manajemen lainnya. Hasil analisis beban kerja juga dapat dijadikan tolok ukur untuk

meningkatkan produktivitas kerja serta langkah-langkah lainnya dalam rangka meningkatkan pembinaan, penyempurnaan dan pendayagunaan aparatur negara baik dari segi kelembagaan, ketatalaksanaan maupun kepegawaian. Upaya tersebut dapat dicapai melalui pelaksanaan analisis beban kerja pada setiap unit organisasi di lingkungan instansi pemerintah secara konsisten dan berkesinambungan.

Di daerah, pengelolaan kepegawaiannya semakin kompleks apalagi semenjak diberlakukannya Undang Undang No. 22 Tahun 1999 Tentang Pemerintahan Daerah yang kemudian direvisi dengan UndangUndang No. 32 Tahun 2004 dilaksanakan. Dari sisi kepegawaian berdampak pada pengalihan lebih dari dua juta pegawai pusat menjadi pegawai daerah. Jumlah yang sedemikian besar menyebabkan pemerintah daerah merasakan adanya kelebihan pegawai dalam unit organisasinya. Jumlah pegawai yang ada tidak diimbangi dengan beban kerja yang memadai yang pada akhirnya menyebabkan pegawai tidak bekerja secara optimal. Disisi lain pemerintah daerah juga melakukan rekrutmen pegawai baik melalui penerimaan CASN maupun dengan pengangkatan pegawai kontrak/tenaga honor sehingga secara pasti menambah jumlah aparatur di daerah. 
Dalam rangka analisis terhadap kebutuhan pegawai negeri sipil, pemerintah melalui Kementerian PAN menerbitkan keputusan Menteri PAN tentang Pedoman Perhitungan Kebutuhan Pegawai Berdasarkan Beban Kerja melalui Kep.Men.PAN Nomor: KEP/75/M.PAN/7/2004. Keputusan tersebut dimaksudkan untuk menjadi acuan bagi setiap instansi pemerintah dalam menghitung kebutuhan pegawai berdasarkan beban kerja dalam rangka penyusunan formasi ASN di lingkungannya. Sedangkan tujuan diterbitkannya keputusan tersebut adalah untuk meningkatkan kualitas perencanaan pegawai, khususnya penyusunan formasi yang rasional dalam rangka mewujudkan penyelenggaraan pemerintahan yang efektif dan efisien.

Table 1.2 berikut menunjukkan dalam 4 tahun terakhir kinerja Sekretariat Daerah Kabupaten Balangan Provinsi Kalimantan Selatan dapat dilihat pada table sebagai berikut:

Tabel 1.2

Kinerja Aparatur Sipil Negara (ASN) Pada Sekretariat Daerah Kabupaten Balangan Provinsi Kalimantan Selatan 3 Tahun Terakhir

\begin{tabular}{|r|r|l|l|}
\hline No & Tahun & Jlh Pegawai & Kinerja \\
\hline 1 & 2017 & 103 & Cukup Baik \\
\hline 2 & 2018 & 103 & Cukup Baik \\
\hline 3 & 2019 & 107 & Baik \\
\hline 4 & 2020 & 105 & Baik \\
\hline
\end{tabular}

Sumber: Data Bagian Umum dan Kepegawaian Kabupaten Balangan Provinsi Kalimantan Selatan

Dari tabel 1.2 diatas bisa disimpulkan bahwa pegawai Aparatur Sipil Negara (ASN) Pada Sekretariat Daerah Kabupaten Balangan Provinsi Kalimantan Selatan berdasarkan penilaian dari atasan pegawai yang dilihat dari SKP/DP 3 persentase kinerja penilaiannya cukup baik dan mendapat kategori baik sejak tahun 2019 dan 2020, ini membuktikan bahwa kinerja pegawai sudah maksimal dalam bekerja di Sekretariat Daerah Kabupaten Balangan Provinsi Kalimantan Selatan.

Berdasarkan kenyataan dan latar belakang dari uraian di atas, sangat perlu penyusunan analisis jabatan, analisis beban kerja dan kompetensi guna meningkatkan kinerja Aparatur Sipil Negara (ASN). Maka dari itu peneliti tertarik mengangkat permasalahan tersebut dalam kajian yang lebih mendalam yaitu "Pengaruh Analisis Jabatan, Analisis Beban Kerja dan Kompetensi Terhadap Kinerja Aparatur Sipil Negara (ASN) Pada Sekretariat Daerah Kabupaten Balangan Provinsi Kalimantan Selatan".

\section{Studi Literatur}

\section{Analisis Jabatan}

\section{Pengertian Analisis Jabatan}

Analisis jabatan (job analysis) adalah suatu cara, prosedur dan kegiatan yang dilakukan untuk mengumpulkan dan menganalisi informasi tentang pekerjaan, berupa: deskripsi pekerjaan, indikator pekerjaan, pendidikan dan kompetensi yang diperlukan, prosedur operasi melaksanakan pekerjaan, hasil pekerjaan serta kompensasi dan penilaian pekerjaan. Analisis jabatan memberikan informasi berharga bagi perusahaan antara lain penentuan strategi penarikan, seleksi, penilaian kinerja, pelatihan dan pengembangan, design dan redesign jabatan dan perencanaan SDM (Armstong, 2009:98).

Analisis jabatan merupakan proses menghimpun dan mempelajari berbagai informasi, yang berhubungan dengan pekerjaan secara operasional dan tanggung jawabnya. Analisis pekerjaan memberikan ringkasan mengenai kewajiban dan tanggung jawab suatu pekerjaan, hubungannya dengan pekerjaan lainnya, pengetahuan dan keterampilan yang dibutuhkan, dan lingkungan kerja dimana pekerjaan tersebut dijalankan.

Tujuan dan Manfaat Analisis Jabatan 
Analisis jabatan menjadi landasan atau pedoman pada perusahaan untuk penerimaan, penempatan, serta penentuan jumlah karyawan. Analisis jabatan digunakan sebagai landasan untuk melaksanakan mutasi, promosi, dan pemberian latihan atau training kepada karyawan serta sebagai dasar pemberian kompensasi. Menurut Sedarmayanti (2010:21), tujuan analisis jabatan adalah sebagai berikut:

1. Penarikan, seleksi dan penempatan karyawan.

2. Sebagai petunjuk dasar dalam menyusun program latihan dan pengembangan.

3. Menilai kinerja/pelaksanaan kinerja.

4. Memperbaiki cara bekerja karyawan.

5. Merencanakan organisasi agar memenuhi syarat/memperbaiki struktur organisasi sesuai beban dan fungsi pekerjaan.

6. Merencanakan dan melaksanakan promosi serta transfer karyawan.

7. Merencanakan fasilitas dan perlengkapan kerja bagi karyawan.

8. Bimbingan dan penyuluhan karyawan.

Aspek-aspek Analisis Jabatan

Analisis jabatan perlu

dilakukan agar dapat mendesain organisasi serta menetapkan uraian pekerjaan (job description), spesifikasi pekerjaan (job spesification) dan evaluasi pekerjaan (job evaluation) Mondy (2008:67). Adapun penjelasan atas ketiga aspek analisis jabatan tersebut adalah sebagai berikut:

a. Uraian pekerjaan (job description)

Uraian pekerjaan adalah informasi tertulis yang menguraikan tugas dan tanggung jawab, kondisi pekerjaan, hubungan pekerjaan, dan aspek-aspek pekerjaan pada suatu jabatan tertentu dalam organisasi. Uraian pekerjaan ini harus diuraikan secara jelas agar para pegawai diharapkan dapat mengenal serta mengetahui tugas apa yang mereka akan lakukan, tanggung jawab serta prestasi apa yang harus dicapainya untuk di kemudian hari. Uraian pekerjaan harus dipedomani oleh semua karyawan agar pekerjaan mereka lebih mudah dilakukan dikarenakan uraian pekerjaan yang terstruktur, jelas dan mudah dimengerti karyawan.

b. Spesifikasi pekerjaan (job spesification)

Spesifikasi jabatan merupakan suatu daftar dari tuntutan manusiawi suatu jabatan, yakni pendidikan keterampilan, kepribadian, dan lainlain sesuai produk dari analisis jabatan. Dalam mengembangkan spesifikasi jabatan perlu mempertimbangkan semua elemen pengetahuan, kemampuan, kecakapan, dan ciri lainnya.

c. Evaluasi pekerjaan (job evaluation)

Evaluasi pekerjaan adalah menilai berat atau ringan, mudah atau sukar, besar atau kecil risiko pekerjaan dan memberikan nama, ranking (peringkat), serta harga atau gaji suatu jabatan. Jika pekerjaan berat, sukar, berisiko besar, dan ranking jabatan semakin tinggi maka harga atau gaji semakin besar, tetapi sebaliknya apabila pekerjaan mudah, ringan, risiko kecil, tanggung jawab kecil dan ranking jabatan rendah, maka gaji nya semakin kecil.

\section{Tahapan Proses Analisis Jabatan}

Proses pelaksanaan analisis jabatan dilakukan dengan tahapan sebagai berikut:

a. Persiapan :

1. Perencanaan proses analisis jabatan.

2. Pembentukan Tim.

3. Pemberitahuan kepada unit organisasi yang akan menjadi sasaran.

4. Penyampaian formulir analisis jabatan dan petunjuk pengisiannya.

b. Pengumpulan Data Jabatan :

1. Pengisian daftar pertanyaan.

2. Wawancara.

3. Observasi.

4. Referensi.

c. Pengolahan Data Jabatan :

1. Penyusunan uraian jabatan.

2. Penyusunan spesifikasi jabatan.

3. Penyusunan peta jabatan.

d. Verifikasi Jabatan 
Hasil pengolahan data jabatan diperiksa kebenarannya melalui pengecekan ulang untuk mengetahui ada tidaknya hal yang perludiperbaiki terhadap informasi jabatan :

1. Identitas Jabatan yang berupa nama jabatan, kode jabatan, letak jabatan, dan ikhtisar jabatan.

2. Nama Jabatan adalah sebutan untuk memberi ciri dan gambaran atas isi jabatan, yang berupa sekelompok tugas yang melembaga atau menyatu dalam satu wadah jabatan, tugas, dan fungsi yang sama sebaiknya menggunakan nama jabatan yang sama.

3. Kode Jabatan adalah kode yang merepresentasikan suatu jabatan, yang dibuat untuk mempermudah inventarisasi jabatan.

4. lkhtisar Jabatan atau ringkasan tugas adalah ringkasan dari tugastugas yang dilakukan, yang tersusun dalam satu kalimat yang mencerminkan pokok-pokok tugas jabatan.

5. Kualifikasi Jabatan adalah persyaratan yang harus dipenuhi oleh pegawai untuk menduduki suatu jabatan, agar dapat melaksanakan tugas dengan baik.

6. Uraian Tugas adalah paparan semua tugas jabatan yang merupakan upaya pokok pemangku jabatan dalam memproses bahan kerja menjadi hasil kerja menggunakan perangkat kerja dalam kondisi tertentu.

7. Hasil Kerja adalah produk yang harus dicapai oleh pemangku jabatan.

8. Bahan Kerja adalah masukan yang diproses dengan tindak kerja (tugas) menjadi hasil kerja.

9. Perangkat Kerja adalah acuan atau pedoman yang digunakan untuk mengolah bahan kerja menjadi hasil kerja.

10. Tanggung Jawab adalah rincian atas segala sesuatu yang dipertanggungjawabkan kepada pemangku jabatan.

11. Wewenang adalah hak dan kekuasaan pemangku jabatan untuk mengambil sikap atau menentukan sikap pengambilan keputusan.

12. Syarat Jabatan adalah persyaratan minimal lain yang dapat dipenuhi oleh pegawai untuk menduduki suatu jabatan, agar dapat melaksanakan tugas dengan baik.

\section{Analisis Beban Kerja Pengertian Beban Kerja}

Beban kerja adalah sejumlah proses atau kegiatan yang harus diselesaikan oleh seorang pekerja dalam jangka waktu tertentu. Apabila seorang pekerja mampu menyelesaikan dan menyesuaikan diri terhadap sejumlah tugas yang diberikan, maka hal tersebut tidak menjadi suatu beban kerja. Namun, jika pekerja tidak berhasil maka tugas dan kegiatan tersebut menjadi suatu beban kerja.Beban kerja adalah sesuatu yang dirasakan berada di luar kemampuan pekerja untuk melakukan pekerjaannya. Kapasitas seseorang yang dibutuhkan untuk mengerjakan tugas sesuai dengan harapan (performa harapan) berbeda dengan kapasitas yang tersedia pada saat itu (performa aktual). Perbedaan diantara keduanya menunjukkan taraf kesukaran tugas yang mencerminkan beban kerja.

\section{Faktor yang Mempengaruhi Beban Kerja}

Menurut Soleman (2011:85), faktor-faktor yang memengaruhi beban kerja adalah sebagai berikut:

a. Faktor eksternal

Adalah beban kerja yang berasal dari luartubuh pekerja, antara lain yaitu:

1. Tugas (Task). Meliputi tugas bersifat seperti, stasiun kerja, tata ruang tempat kerja, kondisi ruang kerja, kondisi lingkungan kerja, sikap kerja, cara angkut, beban yang diangkat. Sedangkan tugas yang bersifat mental meliputi, tanggung jawab, kompleksitas pekerjaan, emosi pekerjaan dan sebagainya. 
2. Organisasi kerja. Meliputi lamanya waktu kerja, waktu istirahat, shift kerja, sistem kerja dan sebagainya.

3. Lingkungan kerja. Lingkungan kerja dapat memberikan beban tambahan yang meliputi, lingkungan kerja fisik, lingkungan kerja biologis dan lingkungan kerja psikologis.

b. Faktor internal

Faktor internal adalah faktor yang berasal dari dalam tubuh akibat dari reaksi beban kerja eksternal yang berpotensi sebagai stresor, meliputi faktor somatis (jenis kelamin, umur, ukuran tubuh, status gizi, kondisi kesehatan, dan sebagainya), dan faktor psikis (motivasi, persepsi, kepercayaan, keinginan, kepuasan, dan sebagainya).

c. Pengukuran Beban Kerja

Pengukuran beban kerja dilakukan untuk memperoleh informasi mengenai tingkat efektivitas dan efisiensi kerja organisasi berdasarkan banyaknya pekerjaan yang harus diselesaikan dalam jangka waktu satu tahun. Menurut O'Donnell dan Eggemeier (1986:76), pengukuran beban kerja dapat dilakukan dalam tiga jenis, yaitu:

a. Pengukuran subjektif

Pengukuran subjektif adalah pengukuran yang didasarkan kepada penilaian dan pelaporan oleh pekerja terhadap beban kerja yang dirasakannya dalam menyelesaikan suatu tugas. Pengukuran jenis ini pada umumnya menggunakan skala penilaian (rating scale).

b. Pengukuran kinerja

Pengukuran kinerja adalah pengukuran yang diperoleh melalui pengamatan terhadap aspek-aspek perilaku/aktivitas yang ditampilkan oleh pekerja. Salah satu jenis dalam pengukuran kinerja adalah pengukuran yang diukur berdasarkan waktu. Pengukuran kinerja dengan menggunakan waktu merupakan suatu metode untuk mengetahui waktu penyelesaian suatu pekerjaan yang dikerjakan oleh pekerja yang memiliki kualifikasi tertentu, di dalam suasana kerja yang telah ditentukan serta dikerjakan dengan suatu tempo kerja tertentu.

c. Pengukuran fisiologis

Pengukuran fisiologis adalah pengukuran yang mengukur tingkat beban kerja dengan mengetahui beberapa aspek dari respon fisiologis pekerja sewaktu menyelesaikan suatu tugas/pekerjaan tertentu. Pengukuran yang dilakukan biasanya pada refleks pupil, pergerakan mata, aktivitas otot dan respon-respon tubuh lainnya.

\section{Pengertian Kompetensi}

Istilah Kompetensi menurut Webster's Dictionary mulai muncul pada tahun 1596. Istilah ini diambil dari kata latin "competere"yang artinya " to be suitable". Kemudian ini secara substansial mengalami perubahan dengan masuknya berbagai isu dan pembahasan mengenai konsep kompetensi dari berbagai literature (Wibowo, 2016:54).

Pengertian kompetensi adalah karakteristik yang mendasari seseorang berkaitan dengan efektivitas kinerja individu dalam pekerjaannya atau karakteristik dasar yang memiliki hubungan kausal atau sebagai sebab-akibat dengan kriteria yang dijadikan acuan, efektif atau berkinerja prima atau superior di tempat kerja atau pada situasi tertentu.

Menurut Spencer dalam Moeheriono (2014:78) kompetensi terletak pada bagian dalam setiap manusia dan selamanya ada pada kepribadian seseorang yang dapat memprediksikan tingkah laku dan performansi secara luas pada semua situasi dan tugas pekerjaan atau jobs task.

\section{Faktor Kompetensi Sumber Daya Manusia}

Michael Zwell (dalam Wibowo, 2016:57) mengungkapkan bahwa terdapat beberapa faktor yang dapat memengaruhi kecakapan kompetensi seseorang, yaitu sebagai berikut: 
1. Keyakinan dan Nilai-nilai

Keyakinan terhadap diri maupun terhadap orang lain akan sangat memengaruhi perilaku. Apabila orang percaya bahwa mereka tidak kreatif dan inovatif, mereka tidak akan berusaha berpikir tentang cara baru atau berbeda dalam melakukan sesuatu.

2. Keterampilan

Keterampilan memainkan peranan di berbagai kompetensi. Berbicara di depan umum merupakan keterampilan yang dapat dipelajari, dipraktikkan, dan diperbaiki. Keterampilan menulis juga dapat diperbaiki dengan instruksi, praktik dan umpan balik.

3. Pengalaman

Keahlian dari banyak kompetensi memerlukan pengalaman mengorganisasi orang, komunikasi di hadapan kelompok, menyelesaikan masalah, dan sebagainya. Orang yang tidak pernah berhubungan dengan organisasi besar dan kompleks tidak mungkin mengembangkan kecerdasan organisasional untuk memahami dinamika kekuasaan dan pengaruh dalam lingkungan tersebut.

4. Karakteristik Kepribadian

Dalam kepribadian termasuk banyak faktor yang di antaranya sulit untuk berubah. Akan tetapi, kepribadian bukannya sesuatu yang tidak dapat berubah. Kenyataannya, kepribadian seseorang dapat berubah sepanjang waktu. Orang merespon dan berinteraksi dengan kekuatan dan lingkungan sekitarnya.

5. Motivasi

Motivasi merupakan faktor dalam kompetensi yang dapat berubah. Dengan memberikan dorongan, apresiasi terhadap pekerjaan bawahan, memberikan pengakuan dan perhatian individual dari atasan dapat mempunyai pengaruh positif terhadap motivasi seseorang bawahan.

6. Isu Emosional

Hambatan emosional dapat membatasi penguasaan kompetensi. Takut membuat kesalahan, menjadi malu, merasa tidak disukai atau tidak menjadi bagian, semuanya cenderung membatasi motivasi dan inisiatif. Perasaan tentangkewenangan dapat mempengaruhi kemampuan komunikasi dan menyelesaikan konflik dengan manajer. Orang mungkin mengalami kesulitan mendengarkan orang lain apabila mereka tidak merasa didengar.

7. Kemampuan Intelektual

Kompetensi tergantung pada pemikiran kognitif seperti pemikiran konseptual dan pemikiran analitis. Tidak mungkin memperbaiki melalui setiap intervensi yang diwujudkan suatu organisasi. Sudah tentu faktor seperti pengalaman dapat meningkatkan kecakapan dalam kompetensi ini.

8. Budaya Organisasi

Budaya organisasi memengaruhi kompetensi sumber daya manusia dalam kegiatan sebagai berikut:

a. Praktik rekrutmen dan seleksi karyawan mempertimbangkan siapa di antara pekerja yang dimasukkan dalam organisasi dan tingkat keahliannya tentang kompetensi.

b. Semua penghargaan mengomunikasikan pada pekerja bagaimana organisasi menghargai kompetensi.

c. Praktik pengambilan keputusan memengaruhi kompetensi dalam memberdayakan orang lain, inisiatif, dan memotivasi orang lain.

d. Filosofi organisasi-misi, visi dan nilai-nilai berhubungan dengan semua kompetensi.

e. Kebiasaan dan prosedur memberi informasi kepada pekerja tentang berapa banyak kompetensi yang diharapkan.

f. Komitmen pada pelatihan dan pengembangan

mengomunikasikan pada pekerja tentang pentingnya kompetensi tentang pembangunan berkelanjutan. 
g. Proses organisasional yang mengembangkan pemimpin secara langsung memengaruhi kompetensi kepemimpinan.

\section{Dimensi dan Indikator Kompetensi}

Beberapa aspek yang terkandung dalam konsep kompetensi menurut Gordon (dalam Sutrisno, 2016:67) sebagai berikut:

1. Pengetahuan (knowledge)

Kesadaran dalam bidang kognitif. Misalnya seorang karyawan mengetahui cara melakukan identifikasi belajar dan bagaimana melakukan pembelajaran yang baik sesuai dengan kebutuhan yang ada dengan efektif dan efisien di perusahaan.

2. Pemahaman (understanding)

Kedalam kognittif dan afektif yang dimiliki individu. Misalnya seorang karyawan dalam melaksanakan pembelajaran harus mempunyai pemahaman yang baik tetang karakteristik dan kondisi secara efektif dan efisien.

3. Kemampuan/Keterampilan (skill)

Sesuatu yang dimiliki oleh individu yang melaksanakan tugas atau pekerjaan yang dibebankan kepadanya. Misalnya, kemampuan karyawan dalam memilih metode kerja yang dianggap lebih efektif dan efisien.

4. Nilai (value)

Suatu standar perilaku yang telah ditakini dan secara psikologis telah menyatu dalam diri seseorang. Misalnya, standar perilaku para karyawan dalam melaksanakan tugas (kejujuran, keterbukaan, demokratis dan lain-lain).

5. Sikap (attitude)

Perasaan (senang-tidak senang, sukatidak suka) atau reaksi terhadap suatu rangsangan yang datang dari luar. Misalnya, reaksi terhadap krisis ekonomi, perasaan terhadap kenaikan gaji dan sebagainya.

6. Minat (interest)
Kecenderungan seseorang untuk melakukan suatu perbuatan. Misalnya, melakukan sesuatu aktivitas tugas.

\section{Kinerja Pegawai \\ Pengertian Kinerja}

Sumber daya manusia sagat penting bagi perusahaan atau organisasi dalam mengelola,mengatur, memanfaatkan pegawai sehingga dapat berfungsi secara produktif untuk tercapainya tujuan. Sumber daya manusia merupakan salah satu faktor produksi potensial, secara nyata. Faktor produksi manusia bukan hanya bekerja secara fisik saja akan tetapi juga bekerja secara fikir. Optimalisasi sumber daya manusia menjadi titik sentral perahtian organisasi dalam meningkatkan kinerja pegawai. Sehingga dapat dikatakan sumber daya manusia adalah sumber yang sangat penting atau faktor kunci untuk mendapakan kinerja yang baik.

Menurut Hasibuan (2011:67) kinerja adalah merupakan suatu hasil kerja yang dicapai seseorang dalam melaksanakan tugas-tugasnya atas kecakapan, usaha dan kesempatan. Berdasarkan paparan diatas kinerja adalah suatu hasil yang dicapai seseorang dalam melaksanakan tugas-tugas yang didasarkan atas kecakapan, pengalaman dan kesungguhan serta waktu menurut standar dan kriteria yang telah ditetapkan sebelumnya. Kinerja karyawan adalah hasil dari proses pekerjaan tertentu secara berencana pada waktu dan tempat dari karyawan serta organisasi bersangkutan menurut Mangkuprawira dan Hubeis (2012:67).

\section{Faktor - Faktor Yang Mempengaruhi Kinerja}

Hasibuan

(2011:37)

menyatakan bahwa: produktivitas adalah perbandingan antara keluaran (output) dengan masukan (input). Faktor-faktor yang mempengaruhi Kinerja menurut Sedarmayanti (2005:110) antara lain: .

1. Sikap mental (motivasi kerja, disiplin kerja, etika kerja);

2. Pendidikan;

3. Keterampilan;

4. Manajemen kepemimpinan; 
5. Tingkat penghasilan;

6. Gaji dan kesehatan;

7. Jaminan sosial;

8. Iklim kerja;

9. Sarana prasarana;

10. Teknologi;

11. Kesempatan berprestasi.

Indikator Kinerja Pegawai

Menurut Keban (2004) dalam

Pasolong (2013:45) pengukuran kinerja pegawai penting dilakukan oleh instansi pelayanan publik. Dengan mengetahui kelemahan dan kelebihan, hambatan dan dorongan, atau berbagai faktor sukses bagi kinerja pegawai serta institusi maka terbukalah jalan menuju profesionalisasi, yaitu memperbaiki kesalahan-kesalahan yang dilakukan selama ini.

Terdapat berbagai teori mengenai indikator kinerja pegawai. Salah satunya indikator kinerja pegawai Fadel (2012:47) mengemukakan beberapa indikator yang digunakan untuk mengukur kinerja pegawai yaitu:

a) Pemahaman atas tupoksi

Dalam menjalankan tupoksi, bawahan harus terlebih dahulu paham tentang tugas pokok dan fungsi masing-masing serta mengerjakan tugas sesuai dengan apa yang menjadi tanggung jawabnya.

b) Inovasi

Memiliki inovasi yang positif dan menyampaikan pada atasan serta mendiskusikanya pada rekan kerja tentang pekerjaan.

c) Kecepatan kerja

Dalam menjalankan tugas kecepatan kerja harus diperhatikan dengan menggunakan mengikuti metode kerja yang ada.

d) Keakuratan kerja

Tidak hanya cepat, namun dalam menyelesaikan tugas karyawan juga harus disiplin dalam mengerjakan tugas dengan teliti dalam bekerja dan melakukan pengecekan ulang

e) Kerjasama

Kemampuan dalam bekerjasama dengan rekan kerja lainya seperti bisa menerima dan menghargai pendapat orang lain.

\section{Penilaian Kinerja Pegawai Negeri Sipil}

Untuk melaksanakan ketentuan

Pasal 78 Undang-Undang Nomor 5 Tahun 2014 tentang Aparatur Sipil Negara, pada 26 April 2019, Presiden Joko Widodo telah menandatangani Peraturan Pemerintah (PP) Nomor 30 Tahun 2019 tentang Penilaian Kinerja Pegawai Negeri Sipil (PNS) atau sekarang dikenal dengan ASN.

Dalam Peraturan Pemerintah

(PP) Nomor 30 Tahun 2019 tentang Penilaian Kinerja Pegawai Negeri Sipil (PNS), Penilaian Kinerja PNS bertujuan untuk menjamin objektivitas pembinaan PNS yang didasarkan pada sistem prestasi dan sistem karier. Penilaian dilakukan berdasarkan perencanaan kinerja pada tingkat individu dan tingkat unit atau organisasi, dengan memperhatikan target, capaian, hasil, dan manfaat yang dicapai, serta perilaku PNS.

Pasal 4 Peraturan Pemerintah

(PP) Nomor 30 Tahun 2019 tentang Penilaian Kinerja Pegawai Negeri Sipil (PNS) berbunyi Penilaian Kinerja PNS dilakukan berdasarkan prinsip:

1. Objektif;

2. Terukur;

3. Akuntabel;

4. Partisipatif; dan

5. Transparan.

Penilaian Kinerja PNS sebagaimana dimaksud Peraturan Pemerintah (PP) Nomor 30 Tahun 2019 tentang Penilaian Kinerja Pegawai Negeri Sipil (PNS), dilaksanakan dalam suatu Sistem Manajemen Kinerja PNS yang terdiri atas:

1. Perencanaan kinerja;

2. Pelaksanaan, pemantauan kinerja, dan pembinaan kinerja;

3. Penilaian kinerja;

4. Tindak lanjut; dan

5. Sistem Informasi Kinerja PNS.

Dalam Peraturan Pemerintah

(PP) Nomor 30 Tahun 2019 tentang Penilaian Kinerja Pegawai Negeri Sipil (PNS)Perencanaan Kinerja terdiri atas penyusunan dan penetapan SKP (Sasaran 
Kinerja Pegawai) dengan memperhatikan Perilaku Kerja.

Proses penyusunan SKP yang dimaksud dalam Peraturan Pemerintah (PP) Nomor 30 Tahun 2019 tentang Penilaian Kinerja Pegawai Negeri Sipil (PNS), dilakukan dengan memperhatikan:

1. Perencanaan strategis Instansi Pemerintah;

2. Perjanjian kinerja;

3. Organisasi dan tata kerja;

4. Uraian jabatan; dan/atau

5. SKP atasan langsung

SKP sebagaimana dimaksud memuat kinerja utama yang harus dicapai seorang PNS setiap tahun. Selain kinerja utama sebagaimana dimaksud, SKP dapat memuat kinerja tambahan," demikian bunyi Pasal 9 ayat (1 dan 2) Peraturan Pemerintah (PP) Nomor 30 Tahun 2019 tentang Penilaian Kinerja Pegawai Negeri Sipil (PNS). SKP bagi pejabat pimpinan tinggi, menurut Peraturan Pemerintah (PP) Nomor 30 Tahun 2019 tentang Penilaian Kinerja Pegawai Negeri Sipil (PNS) ini, disusun berdasarkan perjanjian kinerja Unit Kerja yang dipimpinnya dengan memperhatikan: a. rencana strategis; dan b. rencana kerja tahunan.

SKP bagi pejabat pimpinan tinggi utama, menurut Peraturan Pemerintah (PP) Nomor 30 Tahun 2019 tentang Penilaian Kinerja Pegawai Negeri Sipil (PNS), disetujui oleh menteri yang mengoordinasikan. SKP bagi pejabat pimpinan tinggi madya disetujui oleh pimpinan Instansi Pemerintah. Sedangkan SKP bagi pejabat pimpinan tinggi pratama disetujui oleh pejabat pimpinan tinggi madya.

Disebutkan juga dalam Peraturan Pemerintah (PP) Nomor 30 Tahun 2019 tentang Penilaian Kinerja Pegawai Negeri Sipil (PNS), SKP bagi pejabat pimpinan tinggi yang memimpin unit kerja paling sedikit mencantumkan indikator kinerja yang terkait dengan tugas dan fungsi serta kinerja penggunaan anggaran. "SKP bagi pejabat pimpinan Unit Kerja mandiri sebagaimana dimaksud disetujui oleh menteri atau pejabat pimpinan tinggi yang mengoordinasikannya," bunyi Pasal 16 ayat (1) Peraturan Pemerintah (PP) Nomor 30 Tahun 2019 tentang Penilaian Kinerja Pegawai Negeri Sipil (PNS).

\section{Penelitian Terdahulu}

Sebagai bahan pertimbangan dalam penelitian Pengaruh Analisis Jabatan, Analisis Beban Kerja dan Kompetensi Terhadap Kinerja Aparatur Sipil Negara (ASN), diantaranya dikemukakan oleh :

1. Rande. 2016. Pengaruh Analisis Jabatan, kompetensi dan kualitas kerja Terhadap Kinerja Pegawai Pada Dinas Kesehatan Kabupaten Buol. Analisis regresi linier berganda. Hasilnya menunjukkan; (1) pengaruh Analisis Jabatan dan kompetensi secara bersamaan pada kinerja staf di Dinas Kesehatan Kabupaten Buol. Komposisi pengaruh Analisis Jabatan dan kompetensi pengaruh terhadap kinerja karyawan adalah 78,9\%; (2) Analisis Jabatan dan kompetensi berpengaruh secara parsial pada kinerja karyawan Dinas Kesehatan Kabupaten Buol. Sebagai hasil statistik deskriptif menunjukkan dimensi Kompetensi memperoleh persentase paling tinggi, sedangkan dimensi analisis jabatan yang lebih rendah hal ini menandakan bahwa kompetensi adalah variabel yang paling dominan berpengaruh, adapun persamaan penelitian terdahulu dengan penelitian saat ini adalah sama - sama menggunakan analisa data regresi linier berganda, variabel Analisis Jabatan Kompetendsi dan kinerja pegawai sedangkan perbedaannya adalah tidak menggunakan variabel kualitas kerja dalam penelitian ini, populasi dan sampel, objek dan waktu penelitian.

2. Muhammad Said. 2019. Pengaruh Disiplin, Kompetensi, Tingkat Pendidikan Dan Analisis Beban Kerja Terhadap Kinerja Pegawai Dinas Pendidikan Balikpapan. Regresi Linier 
Berganda, Hasil penelitian diperoleh bahwa Dari hasil pengujian dengan uji regresi, Variabel disiplin, kompetensi dan Analisis Beban Kerja secara bersama-sama berpengaruh secara signifikan terhadap kinerja pegawai Dinas Pendidikan Balikpapan. Ada pengaruh yang signifikan antara variabel disiplin terhadap kinerja pegawai Dinas Pendidikan Balikpapan. Ada pengaruh yang signifikan antara variabel kompetensi terhadap kinerja pegawai Dinas Pendidikan Balikpapan. Ada pengaruh yang signifikan antara variabel Analisis Beban Kerja terhadap kinerja pegawai Dinas Pendidikan Balikpapan, adapun persamaan penelitian terdahulu dengan penelitian saat ini adalah sama - sama menggunakan analisa data regresi linier berganda, variabel Kompetensi dan analisis beban kerja dan kinerja pegawai sedangkan perbedaannya adalah tidak menggunakan variabel bebas disiplin dan Tingkat Pendidikan, populasi dan sampel, objek dan waktu penelitian.

3. Stefanus Ogi. 2018. Pengaruh Analisis Jabatan, Analisis Beban Kerja Dan Disiplin Terhadap Kinerja Pegawai Dinas Sosial Jawa Tengah. Analisis regresi berganda, Hasil uji $F$ menunjukkan bahwa Analisis Jabatan, Analisis Beban Kerja, dan disiplin kerja secara bersama-sama berpengaruh signifikan terhadap kinerja karyawan. Hasil uji $t$ menunjukkan bahwa Analisis Jabatan, Analisis Beban Kerja dan disiplin berpengaruh terhadap kinerja pegawai secara sendiri-sendiri. Analisis korelasi antar dimensi menunjukkan bahwa koordinasi vertikal pada variabel Analisis Jabatan memiliki korelasi yang paling kuat terhadap kinerja pegawai. Berdasarkan temuan tersebut maka kinerja pegawai Dinas Sosial Jawa Tengah dapat dimaksimalkan melalui peningkatan pelaksanaan jenjang karier yang jelas, pembagian beban kerja yang baik dan disiplin korektif (teguran lisan maupun tertulis, adapun persamaan penelitian terdahulu dengan penelitian saat ini adalah sama - sama menggunakan analisa data regresi linier berganda, variabel Analisa jabatan, Analisis Beban Kerja dan kinerja pegawai sedangkan perbedaannya adalah tidak menggunakan variabel bebas disiplin, populasi dan sampel, objek dan waktu penelitian.

4. Andini Ramanti Kharie1, Greis M. Sendow2, Lucky O.H Dotulong.2019, dengan judul Pengaruh Analisis Jabatan, Disiplin Kerja Dan Beban Kerja Terhadap Kinerja Karyawan PT. Bank Rakyat Indonesia (Persero) Tbk Kantor Cabang Ternate. Hasil penelitian ini membuktikan bahwa Analisis Jabatan berpengaruh positif dan signifikan terhadap Kinerja Karyawan, Disiplin Kerja berpengaruh positif dan signifikan terhadap Kinerja Karyawan, Beban Kerja berpengaruh positif dan signifikan Terhadap Kinerja Karyawan, baik secara Simultan maupun Parsial. PT. Bank Rakyat Indonesia (Persero) Tbk Kantor Cabang Ternate harus lebih memperhatikan jabatan yang diberikan kepada karyawan agar sesuai dengan latar belakang pendidikan para karyawan, PT. Bank Rakyat Indonesia (Persero) Tbk Kantor Cabang harus lebih terus meningkatkan disiplin kerja karyawannya dengan melakukan pengawasan yang ketat agar karyawan lebih disiplin mematuhi peraturan perusahaan dan PT. Bank Rakyat Indonesia (Persero) Tbk Kantor Cabang memerhatikan hal yang menyangkut dengan penggunaan waktu kerja karena masih ada karyawan yang bekerjamelebihi jam kerja yang ditentukan untuk menyelesaikan pekerjaannya

5. Kurniawan, Bibit and Sutikno, Bayu and Chasanah, Uswatun (2019) dengan judul Analisis Pengaruh Beban Kerja 
Terhadap Kinerja Pegawai Negeri Sipil Di Seksi Kurikulum Dan Peningkatan Mutu Sekolah Dasar Pada Bidang Pendidikan Dasar Dinas Pendidikan Kabupaten Kebumen. Hasilnya adalah uraian jabatan, beban kerja per jabatan, peta dan bobot jabatan. Hasil beban dari kerja evaluasi jabatan adalah deskripsi kerja, peta jabatan, beban kerja per jabatan, dan bobot jabatan. Kesemua faktor tersebut nantinya berkaitan dengan standar kompetensi , syarat jabatan, indikator kerja pegawai, nilai dan peringkat jabatan. Waktu dalam penelitian ini selama 3 bulan yaitu bulan Juli 2019 sampai dengan bulan September 2019. Pengumpulan data dalam penelitian ini menggunakan beberapa teknik sebagai berikut (Sugiyono, 2011:80): Wawancara, Observasi, Dokumentasi dan Studi pustaka. Penelitian ini merupakan penelitian observasional atau non eksperimental pada pegawai di Seksi Kurikulum dan Peningkatan Mutu Sekolah Dasar pada Bidang Pendidikan Dasar Dinas Pendidikan Kebupaten Kebumen. Pengambilan data dengan menggunakan pendekatan waktu cross sectional yaitu metode pengumpulan data yang dilakukan dengan cara observasi data variabel bebas dan variabel terikatnya hanya satu kali pada satu saat (Notoadmodjo, 2012). Hasil penelitian dapat diambil kesimpulan bahwa total dari rata-rata faktor eksternal dan faktor internal beban kerja pegawai Seksi Kurikulum Dinas Pendidikan Kabupaten Kebumen yaitu faktor eksternal meliputi: tugas-tugas fisik, organisasi kerja, lingkungan kerja dan faktor internal yaitu psikis yang tertinggi adalah tugas-tugas fisik, dengan skor nilai rata-rata 4,12 dan tugas-tugas fisik yang sudah dijalankan pegawai sudah baik dan harus terus dipertahankan dan bila perlu ditingkatkan. Beban kerja pegawai kurang dengan skor nilai rata-rata 3,70, dan harus terus ditingkatkan dengan memberikan bimbingan dan pengarahan. Sedangkan lingkungan kerja juga masih rendah dengan skor nilai rata-rata 3,73 sehingga harus ditingkatkan untuk memperoleh hasil yang lebih baik. Dan psikis (faktor internal) juga masih harus ditingkatkan karena rata-ratanya 3,80. Pegawai harus terus mencari cara dan upaya untuk meningkatkan bimbinan dan arahan dan semua pegawai meningkatkan hasil beban kerja yang lebih baik. Faktor Tugas-tugas yang bersifat fisik pegawai sudah mendapatkan nilai kategori baik. Faktor Organisasi Kerja pegawai yang masih rendah sehingga pegawai menangani masalah kompleks, dengan baik dan pembagian tugas dan wewenang sudah sesuai kurang baik

\section{Metode Penelitian \\ Lokasi Penelitian}

Penelitian ini dilakukan di Sekretariat Daerah Kabupaten Balangan Provinsi Kalimantan Selatan Jl. Jl. Jend. Ahmad Yani No.1, Batu Piring, Paringin Sel., Kabupaten Balangan Provinsi Kalimantan Selatan, Kalimantan Selatan 71662.

\section{Populasi dan Sampel}

Jumlah populasi penelitian yang ada pada Sekretariat Daerah Kabupaten Balangan Provinsi Kalimantan Selatan 2021 yang berjumlah sebanyak 124 (seratus dua puluh empat) pegawai.

Sampel adalah sebagian dari jumlah karakteristik yang dimiliki atau mewakili oleh populasi Sekretariat Daerah Kabupaten Balangan Provinsi Kalimantan Selatan tersebut, mereka ini yang akan menjadi sumber data/ obyek penelitian untuk meneliti pengaruh Analisis Jabatan dan Analisis Beban Kerja terhadap Kinerja ASN Sekretariat Daerah Kabupaten Balangan Provinsi Kalimantan Selatan. Teknik sampling yang digunakan adalah simple random sampling namun penentuan sampelnya memperhatikan strata (tingkatan) yang ada dalam populasi agar benar-benar mewakili kondisi di lapangan. Dalam penelitian ini sampel diambil sebanyak $68 \%$ atau sebanyak 84 
orang karena Sampel yang dapat ditemui dan dilakukan wawancara pada saat penelitian ini dilakukan adalah sebanyak itu

\section{Tekhnik Pengumpulan Data}

Pengumpulan data melalui penyebaran kuisioner yang berisi daftar pertanyaan yang disusun berjenjang berdasarkan skala Likert (Sekaran, 2011; 15); adalah skala yang didesain untuk menelaah seberapa kuat subyek setuju atau tidak setuju dengan pertanyaan pada skala lima titik dengan susunan berikut :

1. Sangat Setuju (SS ) skor 5.

2. Setuju ( S ) skor 4.

3. Ragu-ragu ( R ) skor 3

4. Tidak Setuju (TS ) skor 2.

5. Sangat Tidak Setuju ( STS ) skor 1.

\section{Uji InstrumenPenelitian}

Uji Validitas

Uji validitas adalah untuk mengetahui tingkat kevalidan dari instrumen kuesioner yang digunakan dalam mengumpulkan data. Uji validitas ini dilakukan untuk mengetahui apakah item-item yang tersaji dalam kuesioner benar-benar mampu mengungkapkan dengan pasti apa yang diteliti.

Cara yang digunakan adalah dengan Analisa Item, dimana setiap nilai yang ada pada setiap butir pertanyaan dikorelasikan dengan nilai total seluruh butir pertanyaan untuk suatu variabel dengan menggunakan rumus Korelasi Product Moment (Sugiyono, 2017:78). Lebih lanjut, Sugiyono (2017:78) menyatakan bahwa biasanya syarat minimum untuk dianggap memenuhi syarat adalah kalau $r>0,3$. Jadi apabila korelasi antara butir dengan skor total kurang dari 0,3 maka butir dalam instrumen tersebut dinyatakan tidak valid dengan menggunakan SPSS Versi 21.0.

\section{Uji Reliabilitas}

Uji reliabilitas dimaksudkan untuk mengetahui adanya konsistensi alat ukur dalam penggunaannya, atau dengan kata lain alat ukur tersebut mempunyai hasil yang konsisten apabila digunakan berkalikali pada waktu yang berbeda. Untuk uji reliabilitas ini digunakan Teknik Alpha Cronbach, dimana suatu instrumen dapat dikatakan handal (reliabel) apabila memiliki koefisien keandalan atau alpha sebesar 0,6 atau lebih Arikunto (2016; 53).

\section{Uji Asumsi Klasik}

Model regresi adalah untuk memprediksi terhadap nilai variabel dependen, karena itu harus diperhitungkan besarnya kesalahan (error) yang mungkin terjadi. Walaupun suatu prediksi pasti tidak sempurna, namun error yag dihasilkan, yang jumlahnya sebesar jumlah data (n) seharusnya dapat dianggap normal (Santoso, 2012; 26). Untuk menguji apakah analisis regresi dapat dilakukan terhadap suatu data penelitian maka diperlukan uji asumsi klasik yang terdiri dari :

\section{Uji Normalitas}

Uji normalitas bertujuan untuk menguji apakah dalam model regresi ini error yang dihasilkan mempunyai distribusi normal atau tidak. Uji normalitas dapat dilakukan dengan memakai normal probability plot dengan bantuan komputer dimana penentuan lolosuji dideteksi dengan melihat penyebaran data (titik) pada sumbu diagonal grafik. Jika titik data menyebar di sekitar garis diagonal dan arahnya mengikuti arah garis diagonal, maka model regresi ini dinyatakan memenuhi asumsi normalitas. (Santoso, 2012; 43).

\section{Uji Multikolinieritas}

Model regresi yang baik adalah yang tidak model yang variabelnya tidak berhubungan erat satu sama lain. Hasil yang diharapkan dalam pengujian adalah tidak terjadinya korelasi antar variabel independen. Penentuan lolos uji ini dapat dilakukan dengan cara melihat Variance Inflation Factor (VIF) dan Tolerance. Pedoman model regresi yang lolos uji ini adalah : Mempunyai nilai VIF di sekitar angka 1 dan mempunyai angka Tolerance juga di sekitar angka 1 . (Santoso, 2012; 43)

\section{Uji Heteroskedastisitas}

Uji heteroskedastisitas bertujuan untuk menguji apakah dalam model regresi terjadi ketidaksamaan varians dari residual satu pengamatan ke 
pengamatan yang lain (Ghozali, 2018; 53). Jika varians dari residual satu pengamatan ke pengamatan yang lain tetap, maka disebut homoskedastisitas, dan jika berbeda disebut heteroskedastisitas. Model regresi yang baik adalah yang tidak menghasilkan heteroskedastisitas atau sifat data adalah homogen. Pengujian lolos uji ini adalah menggunakan scatterplot atau diagram serak untuk menguji ada tidaknya heteroskedastisitas. Penentuan lolos tidaknya suatu model regresi terhadap uji ini adalah dengan mendeteksi ada tidaknya pola tertentu pada grafik diagram serak, dimana jika titik data menyebar secara acak, berarti data tidak mengalami heteroskedastisitas dan model regresi layak dipakai.(Santoso, 2012:46)

\section{Uji Regresi Linear Berganda}

Regresi linear berganda adalah teknik analisis yang bertujuan untuk memprediksi besar variabel dependen dengan menggunakan data dari dua atau lebih variabel independe yang sudah diketahui besarnya (Santoso, 2012:47). Rumus analisis regresi linier berganda sebagai berikut:

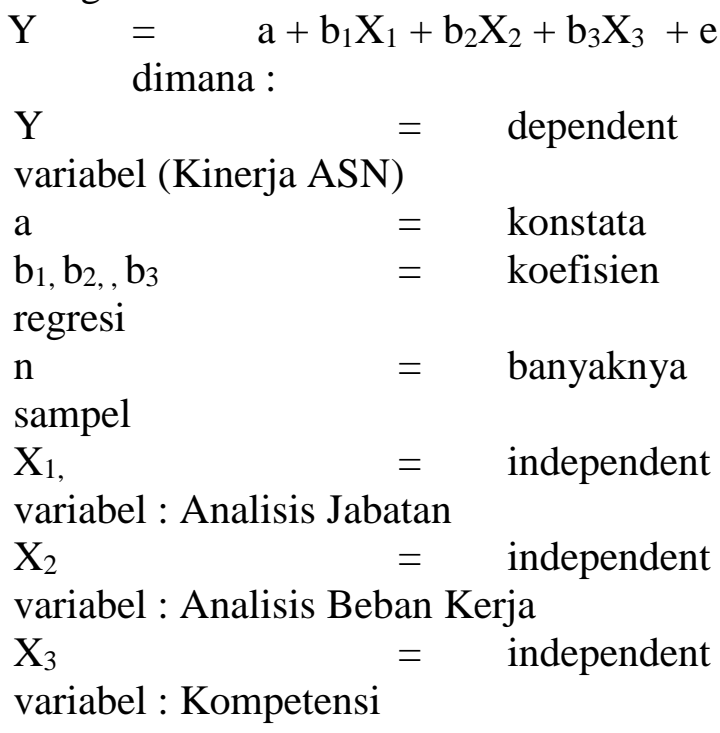

\section{Uji Hipotesis}

\section{Uji Hubungan simultan (Uji F)}

Untuk menguji kebenaran hipotesis hubungan simultan digunakan uji $F$ yaitu untuk menguji keberartian/signifikansi regresi secara bersama-sama/simultan, dimana formulasi hipotesis nihil dan hipotesis alternatipnya sebagai berikut:

$$
\begin{array}{ll}
\mathrm{H}_{0}: & \mathrm{b}_{1}=\mathrm{b}_{2}=\mathrm{b}_{3}=0 \\
\mathrm{H}_{1}: & \mathrm{b}_{1} \neq \mathrm{b}_{2} \neq \mathrm{b}_{3} \neq 0
\end{array}
$$

Pengujian dengan uji $\mathrm{F}$ variansnya adalah dengan membandingkan $F_{\text {hitung }}$ $\left(\mathrm{F}_{\mathrm{h}}\right)$ dengan $\mathrm{F}_{\text {tabel }}\left(\mathrm{F}_{\mathrm{t}}\right)$ pada tarap signifikasi $\alpha=0,05$. Jika $F_{\text {hitung }}\left(F_{h}\right)>$ $\mathrm{F}_{\text {tabel }}\left(\mathrm{F}_{\mathrm{t}}\right)$ maka $\mathrm{H}_{0}$ ditolak dan $\mathrm{H}_{1}$ diterima, begitu pula sebaliknya. Jika $\mathrm{H}_{0}$ diterima, artinya variabel $\mathrm{X}$ secara bersama-sama tidak ada hubungan signifikasi dengan variabel $\mathrm{Y}$, sedangkan jika $\mathrm{H}_{1}$ adalah sebaliknya.

\section{Uji Hubungan parsial (Uji t)}

Untuk menguji kebenaran hipotesis adanya hubungan adalah pengujian secara parsial melalui uji t. Adapun rumusan hipotesis dengan menggunakan Uji $\mathrm{t}$ adalah dengan formulasi hipotesis nihil dan hipotesis alternatipnya sebagai berikut:

$$
\begin{array}{ll}
\mathrm{H}_{0}: & \mathrm{b}_{1}=\mathrm{b}_{2}=\mathrm{b}_{3}=0 \\
\mathrm{H}_{1}: & \mathrm{b}_{1} \neq \mathrm{b}_{2} \neq \mathrm{b}_{3} \neq 0
\end{array}
$$

Pengujian dilakukan melalui uji $t$ dengan membandingkan $t_{\text {hitung }}\left(\mathrm{t}_{\mathrm{h}}\right)$ dengan $t_{\text {tabel }}\left(\mathrm{t}_{\mathrm{t}}\right)$ pada tp signifikasia $\alpha$ 0,05. Apabila hasil perhitungan menunjukkan:

a. $t_{h} \geq t_{t}$ maka $\mathrm{H}_{0}$ ditolak dan $\mathrm{H}_{1}$ diterima

Artinya variabel $\mathrm{X} 1, \mathrm{X} 2$ atau $\mathrm{X} 3$ mempunyai hubungan signifikasn dengan varibel $\mathrm{Y}$ yang diteliti.

b. $t_{\mathrm{h}}<\mathrm{t}_{\mathrm{t}}$ maka $\mathrm{H}_{0}$ diterima dan $\mathrm{H}_{1}$ ditolak

Artinya variasi $\mathrm{X} 1, \mathrm{X} 2$ atau $\mathrm{X} 3$ tidak mempunyai hubungan signifikan dgn variabel $Y$

\section{Uji variabel paling dominan}

Uji dominan dilakukan untuk mencari variabel bebas mana yang paling berpengaruh terhadap variabel terikat, jika dibandingkan dengan beberapa variabel bebas lainnya. Untuk mengetahui variabel dominan ini dapat diketahuid engan melihat nilai koefisien beta (standardized coeficien beta) yang paling besar. 


\section{Validitas dan Reliabilitas}

Hasil uji validitas dan reliabilitas instrument penelitian dapat dilihat pada gambar 5.10 dibawah ini :

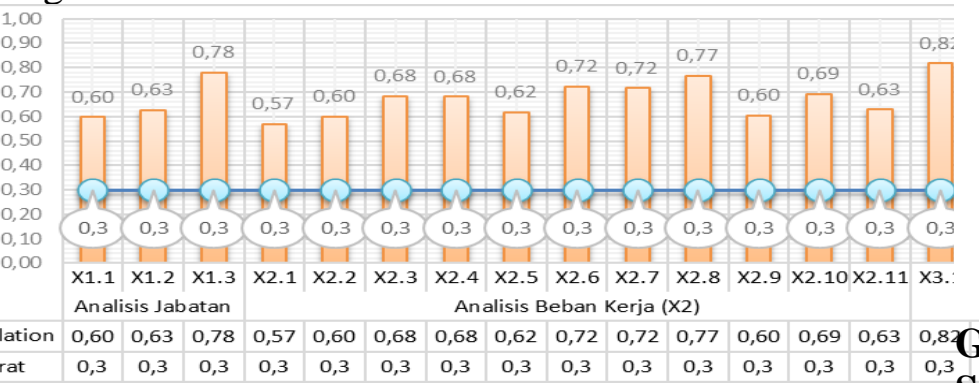

\section{Gambar 5.10 Rekapitulasi Hasil Uji}

\section{Validitas Instrumen Penelitian}

Sumber : Lampiran 4 diolah peneliti

Berdasarkan gambar 5.10 diatas maka menunjukkan bahwa semua item pertanyaan pada variabel independent dan dependent memiliki nilai korelasi lebih besar dari $r_{\text {syarat }}$, instrument penelitian dapat dikatakan valid apabila koefisien korelasinya > dari 0,3 sugiyono dalam Supriyanto dan Machfudz (2010:296) dapat disimpulkan bahwa semua item pertanyaan adalah valid.

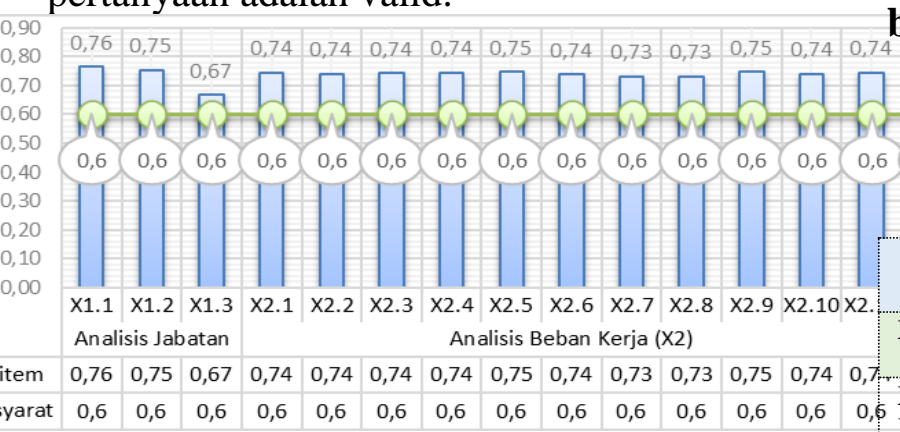

\section{Gambar 5.11 Rekapitulasi Hasil Uji Reliabilitas Instrumen Penelitian}

Sumber : Lampiran 4 diolah peneliti

Berdasarkan data pada Gambar 5.11 di atas dapat diketahui bahwa nilai $\alpha$ item untuk tiap-tiap indikator variabel independent dan dependent memiliki nilai korelasi lebih besar dari syarat, instrument penelitian dapat dikatakan relaibel apabila koefisien $\alpha$ item $>$ dari 0,6 dapat disimpulkan bahwa semua item pertanyaan adalah reliabel atau dapat dipercaya, maka pengujian hipotesa dapat dilakukan menggunakan hasil data.

\section{Uji Asumsi Klasik}

a. Uji Normalitas

\section{b. Uji Multikolinieritas}

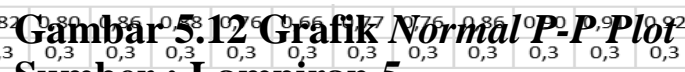
Sumber : Lampiran 5

Berdasarkan gambar 5.12 diatas maka dapat disimpulkan bahwa model regresi berganda dalam penelitian ini tidak ada masalah dalam pengujian normalitas dan layak digunakan dalam penelitian karena titik-titik menyebar di sekitar garis diagonal, serta penyebarannya mengikuti arah garis diagonal, maka grafik tersebut menunjukkan bahwa model regresi layak dipakai karena memenuhi asumsi normalitas.

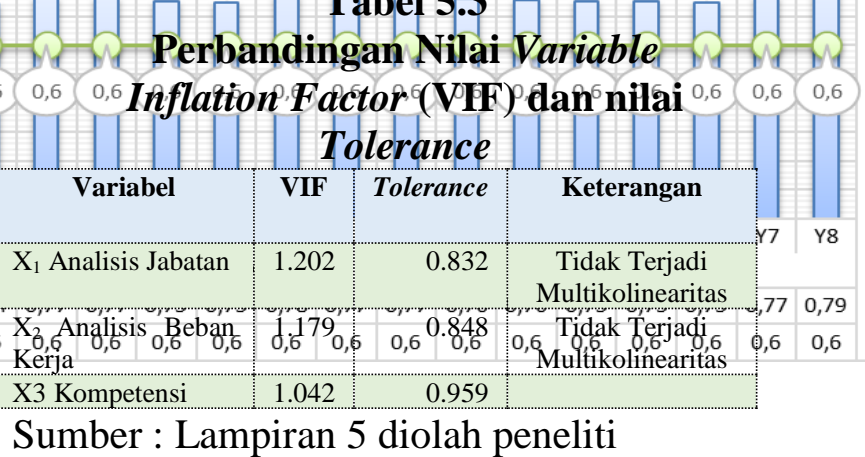

Dari tabel 5.3 diatas menunjukkan hasil perhitungan nilai Tolerance tidak ada variabel independen yang memiliki nilai Tolerance kurang dari 0.10 dengan nilai Tolerance masing-masing variabel independen bernilai analisis jabatan sebesar 0.832, analisis beban kerja sebesar 0.848, dan kompetensi sebesar 0.959. Sementara itu hasil perhitungan nilai Variance Inflation Factor (VIF) juga menunjukkan hal serupa yaitu tidak adanya nilai VIF dari variabel independen yang memiliki nilai VIF lebih dari 10 dengan nilai VIF masing- 
masing variabel independen bernilai analisis jabatan sebesar 1.202, analisis beban kerja sebesar 1.179, dan kompetensi sebesar 1.042. Merujuk hasil perhitungan nilai Tolerance dan VIF dapat disimpulkan bahwa tidak ada multikolinieritas antar variabel independen dalam model regresi.

c. Uji Heteroskedastisidas

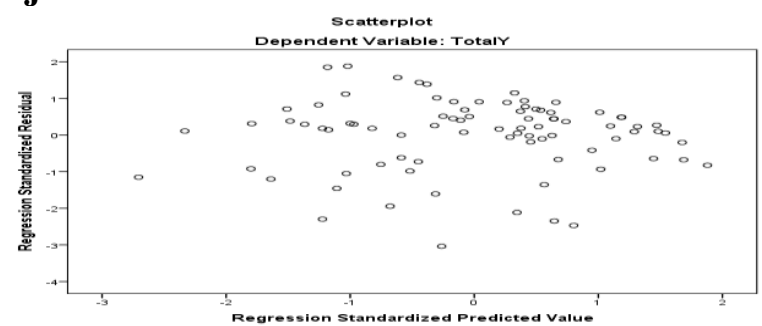

Gambar 5.13 Grafik Scatter Plot

Sumber : Lampiran 5

Berdasarkan gambar 5.13 diatas maka dapat disimpulkan bahwa model regresi berganda dalam penelitian ini terbebas dari heterokesdastisitas dan layak digunakan dalam penelitian karena Titiktitik data menyebar di atas dan di bawah atau di sekitar angka 0, Titik-titik data tidak mengumpul hanya di atas atau di bawah saja dan Penyebaran titik-titik data tidak boleh membentuk pola tertentu.

Analisis Regresi Berganda Variabel Analisis Jabatan (X1), Analisis Beban Kerja (X2) dan Kompetensi (X3) terhadap Kinerja (Y).

Tabel 5.4Rekapitulasi Analisis Regresi

Linier Berganda Pengaruh Analisis Jabatan (X1), Analisis Beban Kerja (X2) dan Kompetensi (X3) Terhadap Kinerja (Y) Aparatur Sipil Negara (ASN)

Sekretariat Daerah Kabupaten Balangan Provinsi Kalimantan Selatan

\begin{tabular}{|l|c:c:c:c}
\hline \multicolumn{1}{|c}{ Variabel } & $\begin{array}{c}\text { Koefisien } \\
\text { Regresi (bi) }\end{array}$ & $\begin{array}{c}\mathrm{t} \\
\mathrm{hitu} \\
\mathrm{ng}\end{array}$ & $\begin{array}{c}\mathrm{t} \\
\mathrm{tab} \\
\mathrm{el}\end{array}$ & $\begin{array}{c}\mathrm{Bet} \\
\mathrm{a}\end{array}$
\end{tabular}

Sumber : Lampiran 5 diolah peneliti

Pada tabel 5.4 dapat dilihat $\mathrm{R}$ Square sebesar 0,383 yang berarti besarnya variasi sumbangan seluruh variabel bebas terhadap variabel terikatnya adalah $38.3 \%$ sedangkan sisanya $62,7 \%$ dijelaskan oleh sebab lain diluar dari penelitian ini. Berdasarkan tabel 5.4 diperoleh persamaan regresi sebagai berikut:

$Y=16,474+1,517 X_{1}+-0,587 X_{2}+$ $0,959 \mathrm{X}_{3}$ ei

Adapun penjelasan dari persamaan regresi diatas adalah sebagai berikut :

1. Konstanta sebesar 16,474 artinya jika variabel analisis jabatan, analisis beban kerja, dan kompetensi terhadap kinerja dianggap konstan, maka nilai kinerja memiliki nilai sebesar 16,474.

2. Variabel analisis jabatan mempunyai nilai 1,517 artinya bahwa setiap terjadi kenaikan analisis jabatan maka kinerja akan mengalami peningkatan. Dengan asumsi variabel lain tetap.

3. Variabel analisis beban kerja mempunyai nilai $-0,587$ artinya bahwa setiap terjadi kenaikan analisis beban kerja maka kinerja akan mengalami penurunan. Dengan asumsi variabel lain tetap.

4. Variabel kompetensi mempunyai nilai 0,959 artinya bahwa setiap terjadi kenaikan kompetensi, maka kinerja akan mengalami peningkatan. Dengan asumsi variabel lain tetap.

\section{Uji Hipotesis}

1. Uji Hipotesis I: Uji F Secara Simultan

Uji ini digunakan dengan tujuan untuk membuktikan apakah variabel bebas berpengaruh secara bersama-sama terhadap variabel terikat. Dalam menjawab hipotesis yang telah diajukan pada awal penelitian, menggunakan alat bantu analisis software SPSS versi 21.00. Dari hasil perhitungan melalui SPSS menunjukan dan signifikansi 0,000 maka dapat disimpulkan variabel bebas berpengaruh signifikan terhadap variabel terikatnya karena signifikansi adalah $0,000<0,05$ dan $F_{\text {hitung }} 16,532$ 
$>$ 2,48, sehingga hipotesis kedua yang mengatakan Analisis Jabatan, Analisis Beban Kerja dan Kompetensi berpengaruh secara simultan Terhadap Kinerja Aparatur Sipil Negara (ASN) Sekretariat Daerah Kabupaten Balangan Provinsi Kalimantan Selatan dapat diterima atau teruji.

2. Uji Hipotesis II: Uji t Secara Parsial

Melalui pengujian ini akan dapat diketahui apakah variabel yang terdiri dari Analisis Jabatan (X1), Analisis Beban Kerja (X2) dan Kompetensi (X3) berpengaruh secara parsial terhadap Kinerja (Y) Pada Sekretariat Daerah Kabupaten Balangan Provinsi Kalimantan Selatan, yaitu dengan cara membandingkan nilai probability signifikansi variabel dengan probability sebesar 5\% $(\alpha=0,05)$ apabila nilai probability signifikansi < $(\alpha=0,05)$ maka terdapat pengaruh signifikan terhadap variabel terikatnya, begitu juga sebaliknya, adapun hasil perhitungan statistik dapat di lihat pada tabel 5.5 dibawah ini :

Tabel 5.5 Nilai t hitung

\begin{tabular}{|c|c|c|c|c|c|}
\hline $\begin{array}{l}\text { Variabe } \\
1 \text { bebas }\end{array}$ & $\begin{array}{c}\mathrm{t} \\
\mathrm{hi} \\
\mathrm{tu} \\
\mathrm{ng}\end{array}$ & $\begin{array}{c}\mathrm{t} \\
\mathrm{ta} \\
\mathrm{b} \\
\mathrm{el}\end{array}$ & $S$ & Keterangan & $\begin{array}{c}\text { Signifika } \\
\text { n atau } \\
\text { tidak } \\
\text { signifikan }\end{array}$ \\
\hline $\begin{array}{l}\text { X1 } \\
\text { Analisis } \\
\text { Jabatan }\end{array}$ & $\begin{array}{c}4 . \\
27 \\
2\end{array}$ & $\begin{array}{l}9 \\
9 \\
0\end{array}$ & $\begin{array}{l}0 \\
0 \\
0\end{array}$ & $\begin{array}{l}0,000<0,05 \\
\text { dan } \quad t_{\text {hitung }} \\
4.272>\mathrm{t}_{\text {tabel }} \\
1,990\end{array}$ & $\begin{array}{c}\text { Signifika } \\
\mathrm{n}\end{array}$ \\
\hline $\begin{array}{l}\mathrm{X} 2 \\
\text { Analisis } \\
\text { Beban } \\
\text { Kerja }\end{array}$ & $\begin{array}{l}- \\
5 . \\
47 \\
4\end{array}$ & $\begin{array}{l}9 \\
9 \\
0\end{array}$ & 0 & $\begin{array}{l}0,000<0,05 \\
\text { dan } t_{\text {hitung }}- \\
5.474>\mathrm{t}_{\text {tabel }} \\
1,990\end{array}$ & $\begin{array}{c}\text { Signifika } \\
\mathrm{n}\end{array}$ \\
\hline $\begin{array}{l}\text { X3 } \\
\text { Kompet } \\
\text { ensi }\end{array}$ & $\begin{array}{c}4, \\
76 \\
6\end{array}$ & $\begin{array}{l}9 \\
9 \\
0\end{array}$ & 0 & $\begin{array}{l}0,000<0,05 \\
\text { dan } t_{\text {hitung }} \\
4,766>\mathrm{t}_{\text {tabel }} \\
1,990\end{array}$ & $\begin{array}{c}\text { Signifika } \\
n\end{array}$ \\
\hline
\end{tabular}

Sumber : Lampiran 5

Berdasarkan tabel 5.5 dapat dilihat Pengaruh variabel Analisis Jabatan (X1) terhadap Kinerja (Y). Hal ini dapat dilihat dari tabel 5.5 dimana memiliki nilai probability signifikansi yaitu $0,000<0,05$ dan $t_{\text {hitung }} 4.272>t_{\text {tabel }} 1,990$, sehingga dapat disimpulkan bahwa Analisis Jabatan (X1) berpengaruh siginifikan secara sendiri - sendiri atau parsial terhadap Kinerja (Y) pada Sekretariat Daerah Kabupaten Balangan Provinsi Kalimantan Selatan .

Pengaruh variabel Analisis Beban Kerja (X2) terhadap Kinerja (Y), Analisis Beban Kerja (X2) berpengaruh signifikan secara parsial terhadap Kinerja (Y). Hal ini dapat dilihat dari tabel 5.5 dimana nilai probability signifikansi yaitu $0,000<$ 0,05 dan $t_{\text {hitung }}-5.474>\mathrm{t}_{\text {tabel }} 1,990$, sehingga dapat disimpulkan bahwa parsial Analisis Beban Kerja (X2) berpengaruh siginifikan secara sendiri - sendiri atau parsial terhadap Kinerja (Y) pada Sekretariat Daerah Kabupaten Balangan Provinsi Kalimantan Selatan.

Pengaruh variabel Kompetensi (X3) terhadap Kinerja (Y), Kompetensi (X3) berpengaruh signifikan secara parsial terhadap Kinerja (Y). Hal ini dapat dilihat dari tabel 5.5 dimana nilai probability signifikansi yaitu $0,000<0,05$ dan $t_{\text {hitung }} 4,766>t_{\text {tabel }} 1,990$, sehingga dapat disimpulkan bahwa parsial Kompetensi (X3) berpengaruh siginifikan secara sendiri - sendiri atau parsial terhadap Kinerja (Y) pada Sekretariat Daerah Kabupaten Balangan Provinsi Kalimantan Selatan.

Dengan demikian hipotesis pertama yang mengatakan Analisis Jabatan, Analisis Beban Kerja dan Kompetensi berpengaruh secara parsial Terhadap Kinerja Aparatur Sipil Negara (ASN) Sekretariat Daerah Kabupaten Balangan Provinsi Kalimantan Selatan adalah benar atau teruji.

\section{Uji Hipotesis III: Variabel Yang} Berpengaruh Dominan 
Pada hipotesa ketiga yang menyatakan bahwa Kompetensi (X3) merupakan faktor yang paling berpengaruh terhadap Kinerja (Y) adalah benar atau terbukti, karena hasil penelitian menunjukkan nilai Beta (Beta Coefficient) Kompetensi (X3) paling besar angkanya 4,766 dibandingkan nilai Beta (Beta Coefficient) Analisis Jabatan (X1) yang hanya 4.272 dan Analisis Beban Kerja (X2) yang hanya -5.474 .

\section{Pembahasan}

Berdasarkan hasil perhitungan
secara keseluruhan, maka dapat
disimpulkan hipotesa secara objektif
sebagai berikut:

1. Pengaruh Analisis Jabatan, Analisis Beban Kerja dan Kompetensi Secara Simultan Terhadap Kinerja

Analisis Jabatan, Analisis

Beban Kerja dan Kompetensi berpengaruh signifikan secara simultan terhadap Kinerja Sekretariat Daerah Kabupaten Balangan Provinsi Kalimantan Selatan, temuan penelitian ini merupakan temuan baru dalam penelitian ini karena dalam penelitian terdahulu tidak ada penelitian yang secara bersamaan meneliti variabel Analisis Jabatan, Analisis Beban Kerja dan Kompetensi Secara bersamaan atau Simultan Terhadap Kinerja. Hasil penelitian ini membuktikan bahwa Analisis Jabatan, Disiplin Kerja dan Beban Kerja berpengaruh secara Simultan Terhadap Kinerja Karyawan, diharapkan Sekretariat Daerah Kabupaten Balangan Provinsi Kalimantan Selatan agar bisa terus menaikkan kinerja pegawainya dengan terus menjaga dan menyeimbangkan perbaikan terahadap ketiga variable ini secara periodik di Lembaga ini.

\section{Pengaruh Analisis Jabatan} Terhadap Kinerja Secara Parsial

Analisis Jabatan berpengaruh signifikan secara parsial terhadap Kinerja Sekretariat Daerah Kabupaten Balangan Provinsi Kalimantan Selatan. Berdasarkan wawancara juga didapat informasi bahwa uraian jabatan dan spesifikasi jabatan pada Sekretariat Daerah Kabupaten Balangan Provinsi Kalimantan selatan sudah berjalan sesuai dengan harapan, dan sesuai dengan aturan menteri dalam negeri. Di dalam hasil analisis jabatan diambil yang berhubungan dengan kepegawaian. Analisis jabatan memiliki peran sebagai alat untuk memudahkan desain ulang dan perubahan pekerjaan.

3. Pengaruh Analisis Beban Kerja Terhadap Kinerja Secara Parsial

Analisis Jabatan berpengaruh signifikan secara parsial terhadap Kinerja Sekretariat Daerah Kabupaten Balangan Provinsi Kalimantan Selatan. Berdasarkan wawancara juga didapat informasi bahwa uraian beban kerja yang tinggi ketika berkerja di Sekretariat Daerah Kabupaten Balangan Provinsi Kalimantan Selatan adalah sekumpulan atau sejumlah kegiatan yang harus diselesaikan oleh suatu unit organisasi atau pemegang jabatan dalam jangka waktu tertentu, berdasarkan hasil penelitian pada umumnya responden menjawab setuju perihal terdapat Pekerjaan yang berlebihan, sering ditemui waktu yang terdesak atau terbatas, Sistem pengawasan yang tidak efisien, Kurang tepatnya pemberian kewenangan sesuai dengan tanggung jawab yang diberikan, Kurang umpan balik prestasi kerja, Terdapat Ketidakjelasan peran, Sering ditemui Perubahan-perubahan dalam pekerjaan, terdapat Konflik antar pribadi dan antar kelompok dan seterusnya, Suasana politik yang tidak aman, ada frustrasi kerja, Perbedaan nilai-nilai lembaga dengan nilai-nilai yang dimiliki pekerjan.

4. Pengaruh Kompetensi Terhadap Kinerja Secara Parsial

Analisis Jabatan berpengaruh signifikan secara parsial terhadap Kinerja Aparatur Sipil Negara (ASN) Sekretariat Daerah Kabupaten Balangan Provinsi Kalimantan Selatan. 
Pada umumnya responden menjawab setuju perihalperbaikan terhadap beberapa hal ini Pengetahuan (knowledge), Pemahaman (understanding),

Kemampuan/Keterampilan (skill), Nilai (value), Sikap (attitude), Minat (interest).. Disarankan untuk menikkan kinerja melalu peningkatan kompetensi adalah perlunya peningkatan kompetensi pegawai melalui pendidikan formal dan informal yang dapat menunjang standar pekerjaan yaitu sub variabel yang tergolong paling rendah dibandingkan dengan sub variabel lainnya. kompetensi, pada dasarnya mampu membentuk kepribadian dan menambah pengetahuan seseorang untuk mengerjakan sesuatu dengan lebih cepat dan tepat. Dengan demikian, dapat dikatakan bahwa semakin tinggi tingkat kompetensi seseorang akan semakin tinggi pula prestasi dan produktivitasnya (kinerjanya) di dalam tugas tertentu.

5. Analisis Beban Kerja Yang Dominan Berpengaruh Terhadap Kinerja

Kompetisi merupakan variabel yang berpengaruh dominan terhadap Kinerja Sekretariat Daerah Kabupaten Balangan Provinsi Kalimantan Selatan dibandingkan dengan variabel lainnya, mengingat ini sangat penting dijaga di dinas ini maka beberapa hal dari Kompetisi yang harus terus dijaga adalah peningkatan pengetahuan (knowledge) pegawai, peningkatan pemahaman (understanding) tentang maksud dan tujuan dari pekerjaan yang di gelutinya, mengasah kemampuan/keterampilan (skill) melalui pelatihan dan pengawasan terhadap pekerjaan pegawai, meningkatkan nilai (value) dari pekerjaan itu, perbaikan sikap (attitude) dari pegawai dalam melaksanakan tugasnya sehari hari, menaikkan minat (interest) dalam bekerja.

\section{Penutup \\ Kesimpulan}

Berdasarkan hasil analisis dan pembahasan yang telah diuraikan pada bab-bab sebelumnya, maka kesimpulan penelitian ini adalah:

1. Pengaruh ketiga variabel Analisis Jabatan, Analisis Beban Kerja dan Kompetensi, tersebut secara simultan (bersama-sama) berpengaruh terhadap Kinerja Aparatur Sipil Negara (ASN) Sekretariat Daerah Kabupaten Balangan Provinsi Kalimantan Selatan.

2. Variabel Analisis Jabatan, Analisis Beban Kerja dan Kompetensi berpengaruh signifikan terhadap Kinerja Aparatur Sipil Negara (ASN) Sekretariat Daerah Kabupaten Balangan Provinsi Kalimantan Selatansecara parsial.

3. Hasil penelitian menyatakan bahwa variabel yang berpengaruh dominan terhadap Kinerja Aparatur Sipil Negara (ASN) Sekretariat Daerah Kabupaten Balangan Provinsi Kalimantan Selatan adalah Analisis Beban Kerja.

\section{Saran}

1. Hasil Penelitian menunjukkan Analisis Jabatan berpengaruh terhadap Kinerja maka disarankan dalam menempatkan Aparatur Sipil Negara (ASN) pihak Sekretariat Daerah Kabupaten Balangan Provinsi Kalimantan Selatan haruslah mengadakan analisis jabatan terlebih dahulu agar didapat deskripsi jabatan dan spesifikasi jabatan, sehingga akan mendapatkan Aparatur Sipil Negara (ASN) yang tepat sesuai dengan kebutuhan Sekretariat Daerah Kabupaten Balangan Provinsi Kalimantan Selatan dan sesuai dengan prinsip "menempatkan orang-orang yang tepat pada tempat yang tepat dan pada waktu yang tepat". Sehingga orang dibutuhkan sesuai dengan kebutuhan dan keinginan Sekretariat Daerah Kabupaten Balangan Provinsi Kalimantan Selatan maka apa yang 
akan menjadi tujuan Sekretariat Daerah Kabupaten Balangan Provinsi Kalimantan Selatan akan tercapai sebagaimana yang menjadi harapan bagi Sekretariat Daerah Kabupaten Balangan Provinsi Kalimantan Selatan

2. Hasil Penelitian yang menunjukkan beban kerja berpengaruh negatif dan signifikan terhadap kinerja Aparatur Sipil Negara (ASN), oleh karena itu yang menjadi saran dari peneliti yaitu tetap memperhatikan beban kerja jangan sampai mengalami kenaikan yang dapat menyebabkan menurunnya potensi kinerja Aparatur Sipil Negara (ASN). Untuk mempertahankan hasil dari kinerja Aparatur Sipil Negara (ASN) yang baik, sebaiknya Sekretariat Daerah Kabupaten Balangan Provinsi Kalimantan Selatan memperhatikan variabel lain yang menjadi pengaruh yang sangat penting bagi kinerja Aparatur Sipil Negara (ASN). Jika ada peneliti lain yang ingin meneliti tentang kinerja Aparatur Sipil Negara (ASN) pada Kantor Sekretariat Daerah Kabupaten Balangan Provinsi Kalimantan Selatan, ada baiknya untuk meneliti variabel lain selain variabel beban kerja yang dapat berpengaruh terhadap kinerja Aparatur Sipil Negara (ASN), mungkin seperti kompensasi, lingkungan

kerja, kepuasan kerja, kepemimpinan, dan lain sebagainya.

3. Hasil penelitian yang menunjukkan bahwa Kompetensi SDM merupakan variabel yang berpengaruh dominan terhadap Kinerja Aparatur Sipil Negara (ASN) Sekretariat Daerah Kabupaten Balangan Provinsi Kalimantan Selatan, kedepannya Kompetensi Sumber Daya Manusia pada Sekretariat Daerah Kabupaten Balangan Provinsi Kalimantan Selatanharus dimiliki semua Aparatur Sipil Negara (ASN) seperti, Kompetensi Pengetahuan yang meliputi pendidikan, dimana jabatan fungsional umum hendaknya diisi sesuai dengan pendidikan Aparatur Sipil Negara (ASN) sesuai dengan Peraturan Menter PAN - RB nomor 26 tahun 2016 tentang Nomenklatur Jabatan Pelaksana Bagi Aparatur Sipil Negara (ASN) Negeri Sipil di Lingkungan Instansi Pemerintah, selain pengetahuan Kompetensi Keterampilan Juga Perlu di Perhatikan dari pengalaman Aparatur Sipil Negara (ASN) sebelumnya serta Kompetensi sikap Aparatur Sipil Negara (ASN) dalam menghadapi pekerjaan, apabila ketiga Kompetensi Sumber Daya Manusia tersebut di miliki Aparatur Sipil Negara (ASN) Sekretariat Daerah Kabupaten Balangan Provinsi Kalimantan Selatan maka kinerja Aparatur Sipil Negara (ASN) pun akan dengan mudah meningkat.

4. Bagi peneliti selanjutnya, hasil penelitian ini bisa digunakan sebagai bahan perbandingan dan referensi untuk penelitian, dan sebagai bahan pertimbangan untuk lebih memperdalam penelitian selanjutnya dengan menggunakan variabel yang berbeda seperti : Motivasi, semnagat kerja, disiplin kerja, kepemimpinan dan lain lain yang dapat di ukur dengan variabel yang berpengaruh terhadap tingkat kinerja Aparatur Sipil Negara (ASN) Sekretariat Daerah Kabupaten Balangan Provinsi Kalimantan Selatan.

\section{DAFTAR PUSTAKA}

Agus Dharma 2014 Manajemen Supervisi. Jakarta, Raja Grafindo Persada,.

Alwi, Syafaruddin. 2001. Manajemen

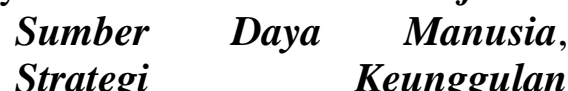
Strategi Keunggulan Kompetitif. Yogyakarta: BPFE UGM.

Arikunto, S. 2016. Prosedur Penelitian Suatu Pendekatan Praktik. Jakarta: Rineka Cipta

Armstrong, Michael. 2009. Armstrong's Handbook of Human Resource. Management Practice 11th Edition. United Kingdom 
Danang, Sunyoto. 2012. Manajemen Sumber Daya Manusia. Jakarta: PT Buku. Seru.

Davis, Keith dan Newstrom, John W. 1985. Perilaku Dalam Organisasi. Jakarta: Erlangga.

Dessler, Gary. 2015. Manajemen Sumber Daya Manusia. Jakarta: Salemba Empat.

Donnelly, Gibson dan ivancevich. 1993. Perilaku Struktur Proses. Jakarta: Erlangga.

Edy, Sutrisno, 2016, Manajemen Sumber Daya Manusia, Jakarta, Kencana Prenada. Media Group.

Ghozali, Imam. 2018. Aplikasi Analisis Multivariate dengan Program IBM. SPSS 25. Semarang: Badan Penerbit Universitas Diponegoro

Gibson, James.,L.,Jhon M., Ivancevich.,dan H.,Donnelly., Jr. 2008: Organisasi Dan Manajemen,Perilaku, Struktur, Dan Proses, terjemahan oleh Joerban Wahid, Jakarta, Erlangga.

Gomes, Faustino Cardoso. 2011. Manajemen Sumber Daya Manusia. Edisi Kedua. Yogyakarta, Penerbit Andi Offset.

Harbani, Pasolong 2013. Kepemimpinan Birokrasi. Bandung : CV.Alfabeta.

Hasibuan, Malayu S.P. 2011. Manajemen Sumber Daya Manusia. Jakarta: Bumi Aksara.

Hutapea, Parulian dan Nurianna Thoha, 2008, Kompetensi Plus : Teori, Desain, Kasus dan Penerapan untuk HR dan Organisasi yang Dinamis, Penerbit : Jakarta, Gramedia Pustaka Utama.

Keban, Yeremias T. 2004. Enam Dimensi Strategis Administrasi Publik, Konsep,. Teori dan Isu. Yogyakarta: Gava Media.
Keputusan Kepala Badan Kepegawaian Negeri Nomor: 46A tahun 2003, tentang pengertian kompetensi

Keputusan Menteri Pendayagunaan Aparatur Negara No: Kep/75/M.Pan/7/2004.

Pedoman Perhitungan Kebutuhan Pegawai Berdasarkan Beban Kerja dalam Rangka Penyusunan Formasi Pegawai Negeri Sipil.

Kunandar, 2007, Guru Profesional Implementasi Kurikulum Tingkat Satuan Pendidikan (KTSP) dan Sukses dalam Sertifikasi Guru, Jakarta: Rajawali Pers

Mangkunegara A.A Anwar Prabu 2009. Manajemen Sumber Daya Manusia Perusahaan. Bandung : PT.Remaja Rosdakarya

Mangkuprawira, S., dan A.V. Hubeis, 2012, Manajemen Mutu Sumber Daya. Manusia. Bogor, Penerbit Ghalia Indonesia.

Masri Singarimbun. 2011. Metode Penelitian Survai. Jakarta: LP3ES

Mathis, Robert \&H. Jackson, John. 2011. Human Resource Management (edisi 10). Jakarta : Salemba Empat

Miner, 2008, Organizational Behavior, Performance \& Productivity, New York, at Buffallo, State. University,.

Moeheriono, 2014, Pengukuran Kinerja Berbasis Kompetensi Edisi Revisi,. Jakarta: PT Raja Grafindo Persada

Moekijat. 2004. Manajemen Tenaga Kerja dan Hubungan Kerja. Bandung: Pioner Jaya.

Mondy, R Wayne. 2008. Manajemen Sumber Daya Manusia. Jakarta: Erlangga.

Munandar. 2001. Stress dan keselamatan Kerja, Psikologi Industri dan organisasi. Jakarta: Universitas Indonesia. 
O’Donnell dan Eggemeier. 1986. Workload Assessment Methodology. New York: Wiley.

Peraturan Menteri PANRB No. 1 Th 2020 tentang Pedoman Analisis Jabatan dan Analisis Beban Kerja

Peraturan Pemerintah (PP) No. 23 Tahun 2004, tentang Badan Nasional Sertifikasi Profesi (BNSP)

Permendagri No.12 Tahun 2008. Pedoman Analisis Beban Kerja di Lingkungan Departemen Dalam Negeri dan Pemerintah Daerah.

PP Nomor 11 Tahun 2017 tentang Manajemen PNS

PP Nomor 30 Tahun 2019 tentang Penilaian Kinerja Pegawai Negeri Sipil (PNS)

PP Nomor 49 Tahun 2018 tentang Manajemen PPPK

Riduwan. 2015. Dasar-Dasar Statistika, Bandung: Alfabeta

Santoso, Singgih. 2012. Panduan Lengkap SPSS Versi 20. Jakarta: PT Elex Media. Komputindo

Sedarmayanti. 2010. Sumber Daya Manusia dan Produktivitas Kerja. Bandung: Mandar Maju.

Sekaran, Uma. 2011. Research Methods For Business (Metode Penelitian Untuk. Bisnis). Jakarta: Salemba Empat

Simamora, Henry 2015. Manajemen Sumber Daya Manusia.Yogyakarta: STIEY

Soleman, Aminah. 2011. Analisis Beban Kerja Ditinjau Dari Faktor Usia Dengan Pendekatan Recommended Weiht Limit. Jurnal Arika, Vol.05 No.02.

Sugiyono. 2017. Metode Penelitian Kuantitatif, Kualitatif, dan $\boldsymbol{R} \& \boldsymbol{D}$. Bandung : Alfabeta, CV.

UU Nomor 5 Tahun 2014 Tentang Aparatur Sipil Negara (ASN)
Wibowo, 2016. Manajemen Kinerja, Edisi Kelima, Jakarta, PT.Rajagrafindo Persada.

Wirawan. 2015. Evaluasi Kinerja Sumber Daya Manusia: Teori, Aplikasi dan Penelitian. Jakarta: Salemba Empat.

Yustiono, 2011. Kinerja dan Penilaian Kinerja.

http://www.stialanbandung.ac.id , diakses tanggal 3 November 2020 